\section{Salinity Tolerance of Sophora secundiflora and Cercis canadensis var. mexicana}

\author{
Genhua Niu ${ }^{1}$ and Denise S. Rodriguez \\ Texas AgriLife Research and Extension Center at El Paso, Texas A\&M \\ University, El Paso AREC, 1380 A\&M Circle, El Paso, TX 79927
}

\section{Mengmeng Gu \\ Department of Plant and Soil Sciences, Mississippi State University, MS 39762}

Additional index words. Mexican redbud, Texas mountain laurel, saline water irrigation, water reuse

\begin{abstract}
Use of reclaimed water to irrigate urban landscapes will likely increase because fresh water supply is diminishing and the population continues to grow in the semiarid southwestern United States. Salt tolerance of two native landscape woody ornamentals, Texas mountain laurel (Sophora secundiflora) and Mexican redbud (Cercis canadensis var. mexicana), was investigated in a greenhouse experiment. Seedlings of the two species were grown in two substrates mixed with composted mulch and a commercial potting mix at two ratios and irrigated with saline solutions at three salinity levels: 1.6 (control, nutrient solution), 3.0, or $6.0 \mathrm{dS} \cdot \mathrm{m}^{-1}$ electrical conductivity (EC). There was no interaction between substrate and EC of irrigation water. Foliar salt damages such as leaf drop, leaf curl, and edge burn were observed in Mexican redbud when the plants were irrigated with solutions at EC of 3.0 and $6.0 \mathrm{dS} \cdot \mathrm{m}^{-1}$. No symptoms were observed on Texas mountain laurel plants, although plants irrigated at $E C$ of 3.0 and $6.0 \mathrm{dS} \cdot \mathrm{m}^{-1}$ were smaller compared with controls. Shoot growth and elongation of both species were reduced by the elevated salinity of irrigation water, and the reduction in Mexican redbud was greater than Texas mountain laurel. Leaf photosynthesis rate and leaf stomatal conductance were also reduced in Texas mountain laurel by the elevated salinity of irrigation water. Tissue $\mathrm{Na}^{+}$and $\mathrm{Cl}^{-}$concentrations were higher in Texas mountain laurel irrigated with water of elevated salinity.
\end{abstract}

As urban population increases and fresh water supply is diminishing in the southwestern United States, many municipalities have encouraged using reclaimed water (treated municipal effluent, also called recycled water) for landscape irrigation. In the past decades, reclaimed water has been used for landscape irrigation, mostly gulf courses, school yards, and parks, in California and the other southwestern states (Dobrowolski et al., 2008) and in other countries (Gori et al., 2000; Marosz, 2004). However, use of reclaimed water for irrigating landscapes with multiple plant species has not been widely practiced partly as a result of salt damage on sensitive plant species. Reclaimed water contains beneficial nutrients for plant growth, but also contains an elevated salt load (Devitt et al., 2005). Therefore, investigating the salinity tolerance of native land-

Received for publication 2 Nov. 2009. Accepted for publication 4 Jan. 2010.

We gratefully acknowledge the financial support from Cooperative State Research, Education and Extension Service, U.S. Department of Agriculture under Agreement No. 2005-34461-15661.

${ }^{1}$ To whom reprint requests should be addressed; e-mail gniu@ag.tamu.edu. heat- and drought-tolerant and thrives in well-drained soil (Gilman and Watson, 1993). Both species are considered excellent landscapes plants in Texas and the other southwestern states (Gilman and Watson, 1993, 1994; Ruter and Ingram, 1991). Despite their ornamental values, little information is available on their salt tolerance. The objective of this study was to examine the relative salt tolerance of these two native woody species by growing them in two substrates irrigated with saline solutions at elevated salinity levels.

\section{Materials and Methods}

Seeds of Texas mountain laurel, treated with concentrated sulfuric acid for $30 \mathrm{~min}$ (Ruter and Ingram, 1991), were sown on 20 Nov. 2006 in plug cells $(63 \mathrm{~mL})$ filled with a germination mix of perlite, vermiculite, and peatmoss at 1:1:1 (by vol.). Seedlings were transplanted on 17 Jan. 2007 to $1.8-\mathrm{L}$ pots containing 1:1 (by vol.) mix of Sunshine Mix \#4 (SunGro Hort., Bellevue, WA) and composted mulch (Western Organics, Inc., Tempe, AZ) amended with $5 \mathrm{~kg} \cdot \mathrm{m}^{-3}$ dolomitic limestone (Carl Pool Earth-Safe Organics, Gladewater, TX) and $1 \mathrm{~kg} \cdot \mathrm{m}^{-3}$ Micromax (Scotts, Marysville, OH). Mexican redbud seeds were scarified on 29 Nov. 2006 with concentrated sulfuric acid for $30 \mathrm{~min}$ followed by cold treatment at $4{ }^{\circ} \mathrm{C}$ for 2 months before germination. The same germination medium and growing substrates for Texas mountain laurel were used for Mexican redbud. From early May to mid-Sept. 2007 , plants of both species were grown in a shade house with $25 \%$ light exclusion. On 2 Oct. 2007, all plants were transplanted to 2.6-L pots containing two types of substrates described subsequently.

To create differences in drainage of the growing substrates, Sunshine Mix \#4 was blended with composted mulch at $1: 1$ or $1: 4$ (by vol.) amended with $5 \mathrm{~kg} \cdot \mathrm{m}^{-3}$ dolomitic limestone and $1 \mathrm{~kg} \cdot \mathrm{m}^{-3}$ Micromax. Sunshine Mix \#4 contained Canadian sphagnum peat, perlite, gypsum, powdered dolomitic limestone, wetting agent, and a low fertilizer charge. The composed mulch comprised wood byproducts, greenwaste, and gypsum. A control nutrient solution was made by adding $0.5 \mathrm{~g} \cdot \mathrm{L}^{-1}$ of $20 \mathrm{~N}-8 \mathrm{P}-16 \mathrm{~K}$ (Peter's 20-20-20; The Scotts Company LLC, Allentown, PA) to tap water resulting in a nutrient solution with electrical conductivity (EC) of $1.6 \mathrm{dS} \cdot \mathrm{m}^{-1}$. The major ions in tap water were $\mathrm{Na}^{+}, \mathrm{Ca}^{2+}, \mathrm{Mg}^{2+}, \mathrm{Cl}^{-}$, and $\mathrm{SO}_{4}{ }^{2-}$ at $184,52.0$, 7.5, 223.6, and $105.6 \mathrm{mg} \cdot \mathrm{L}^{-1}$, respectively. Solutions of moderate and high salinity levels (EC of 3.0 and $6.0 \mathrm{dS} \cdot \mathrm{m}^{-1}$ ) were created by adding appropriate amounts of sodium chloride $(\mathrm{NaCl})$, magnesium sulfate heptahydrate $\left(\mathrm{MgSO}_{4} \cdot 7 \mathrm{H}_{2} \mathrm{O}\right)$, and calcium chloride $\left(\mathrm{CaCl}_{2}\right)$ at $87: 8: 5$ (by weight) to the nutrient solution. The composition of the elevated saline solutions was similar to that of the reclaimed water from local water utilities. A 100-L tank of saline solution was prepared each time for each treatment with confirmed 
EC. Plants were hand-watered when the volumetric moisture contents were below an average of $18 \%$ measured by a theta probe at the upper $6 \mathrm{~cm}$ of the substrate (Type $\mathrm{HH} 2$; Delta-T Devices, Cambridge, U.K.) with an average of $10 \%$ leaching fraction. Saline solution irrigation treatments were initiated on 31 Oct. 2007 for both species and ended on 15 Apr. 2008 for Mexican redbud and 12 May 2008 for Texas mountain laurel. Mexican redbud was ended earlier because defoliation occurred in most plants treated with saline water. Also, growth of the control plants might have become restricted by the container size $(2.6 \mathrm{~L})$ if the experiment had continued. On $145 \mathrm{~d}$ after treatment initiation (26 Mar.), all containers were flushed with tap water to leach out the accumulated salts in the substrates reflected by increasing ECs of the leachate. Leaching fraction was then increased to $30 \%$ to $50 \%$.

The greenhouse environmental conditions were monitored and hourly averages were recorded by a data logger (21X; Campbell Scientific, Logan, UT). The average daily air temperature in the greenhouse during the experiment was maintained at $23 \pm 3{ }^{\circ} \mathrm{C}$ (mean \pm SD). Daily light integral was $15 \pm$ $5 \mathrm{~mol} \cdot \mathrm{m}^{-2} \cdot \mathrm{d}^{-1}$ with a photoperiod of $16 \mathrm{~h} \cdot \mathrm{d}^{-1}$ provided by extending daylength using inflorescent lamps at a photosynthetic photon flux $(P P F)$ of $15 \mu \mathrm{mol} \cdot \mathrm{m}^{-2} \cdot \mathrm{s}^{-1}$ at canopy level.

Plant height, the number of shoots, and the total length of shoots were recorded four times during the experiment. Leachate was collected for EC measurement on four plants for each of the six treatments on a monthly basis. On termination, in addition to plant shoot height, the number of shoots, and the total length of shoots, fresh weight of shoots and roots was recorded. Dry weights (DWs) of the shoots and roots were determined after they were oven-dried at $70{ }^{\circ} \mathrm{C}$ until constant weight.

Leaf net photosynthesis $\left(\mathrm{P}_{\mathrm{n}}\right)$, transpiration $\left(\mathrm{T}_{\mathrm{r}}\right)$, and $g_{\mathrm{S}}$ were measured on four plants for each of the six treatments for Texas mountain laurel on 7 Apr. 2008. As a result of poor performance, $\mathrm{P}_{\mathrm{n}}, \mathrm{T}_{\mathrm{r}}$, and $g_{\mathrm{S}}$ of Mexican redbud plants (leaves defoliated in treatment of EC 3 and EC 6) were not measured. The most recently matured leaf was placed in the cuvette of a portable photosynthesis measurement system (CIRAS-2; PP Systems, Amesbury, MA). The environmental conditions in the cuvette were controlled at leaf temperature $=25{ }^{\circ} \mathrm{C}, P P F=1000$ $\mu \mathrm{mol} \cdot \mathrm{m}^{-2} \cdot \mathrm{s}^{-1}$, and $\mathrm{CO}_{2}$ concentration $=400$ $\mu \mathrm{mol} \cdot \mathrm{mol}^{-1}$. Data were recorded when the environmental conditions and gas exchange parameters in the cuvette became stable. These measurements were taken between $1000 \mathrm{HR}$ and $1200 \mathrm{HR}$.

To analyze $\mathrm{Na}^{+}$and $\mathrm{Cl}^{-}$concentrations for Texas mountain laurel (Mexican redbud plants were not sampled as a result of defoliation), four leaf samples for each of the six treatments were randomly collected at the end of the experiment, washed three times with deionized water, and oven-dried at $70{ }^{\circ} \mathrm{C}$ for $72 \mathrm{~h}$. Dried leaves were ground to pass a 40-mesh screen with a stainless Wiley mill and the samples were submitted to the Soil, Water, and Air Testing Laboratory at New Mexico State University (Las Cruces, NM) for $\mathrm{Na}^{+}$and $\mathrm{Cl}^{-}$analyses. $\mathrm{Na}^{+}$concentrations were determined by EPA method 200.7 [U.S Environmental Protection Agency (EPA), 1983] and analyzed on an ICAP Trace Analyzer (Thermo Jarrell Ash, Franklin, MA). $\mathrm{Cl}^{-}$was determined by EPA method 300.0 (U.S. EPA, 1983) and analyzed using an Ion Chromatograph (Dionex, Sunnyvale, CA).

Data were analyzed separately by species and by each repeated measurement (shoot length, plant height, and leachate EC). For each species, the experiment was a splitplot design with salinity of irrigation water as the main plot and the substrate as subplots with 10 replications. Data were analyzed using PROC GLM procedure with SAS software (Version 9.1.3; SAS Institute Inc., Cary, NC) and means were separated by Student-Newman-Keuls multiple comparison at $P=0.05$.

\section{Results and Discussion}

All plants survived regardless of treatment and species. For Texas mountain laurel, there was no foliar salt injury. However, redbud plants had various levels of defoliation when irrigated with saline water at 3.0 and $6.0 \mathrm{dS} \cdot \mathrm{m}^{-1}$. Salt damage such as leaf marginal burn and leaf curling were also observed on Mexican redbud plants irrigated with saline solution at 3.0 and $6.0 \mathrm{dS} \cdot \mathrm{m}^{-1}$. These foliar injuries were more severe at $6.0 \mathrm{dS} \cdot \mathrm{m}^{-1}$ compared with $3.0 \mathrm{dS} \cdot \mathrm{m}^{-1}$.

There were no interactions between the salinity of irrigation and substrate on any measurements. No differences between the two substrates were found in any growth parameter and leachate EC for either species. Although the physical properties were not formally measured, the differences in waterholding capacity between the two substrates were small based on the changes of substrate moisture contents of the two substrates over time (data not shown). Leachate EC increased with time in all treatments for both species as a result of a low leaching fraction $(\approx 10 \%$ on average) (Fig. 1). Six weeks after the initiation of saline water treatments, leachate EC was 2 to $4 \mathrm{dS} \cdot \mathrm{m}^{-1}$ higher than that of irrigation solution at 3.0 and 6.0 $\mathrm{dS} \cdot \mathrm{m}^{-1}$. By Day 140 , the leachate EC was more than twice of the EC of irrigation solutions; leachate EC was $\approx 8.0$ and 14 $\mathrm{dS} \cdot \mathrm{m}^{-1}$ for irrigation solution of 3.0 and 6.0 $\mathrm{dS} \cdot \mathrm{m}^{-1}$, respectively. In the present study, the substrate components were similar for the two substrates and similar salt accumulation occurred, although the component ratios were different. Previous research reported that leaching fraction and plant species affected leachate EC or salt accumulation when plants were irrigated with saline solutions in addition to the type of substrate (Bernstein et al., 2006; Bole et al., 1981; $\mathrm{Ku}$ and Hershey, 1991; Niu and Rodriguez, 2006a, 2006b).
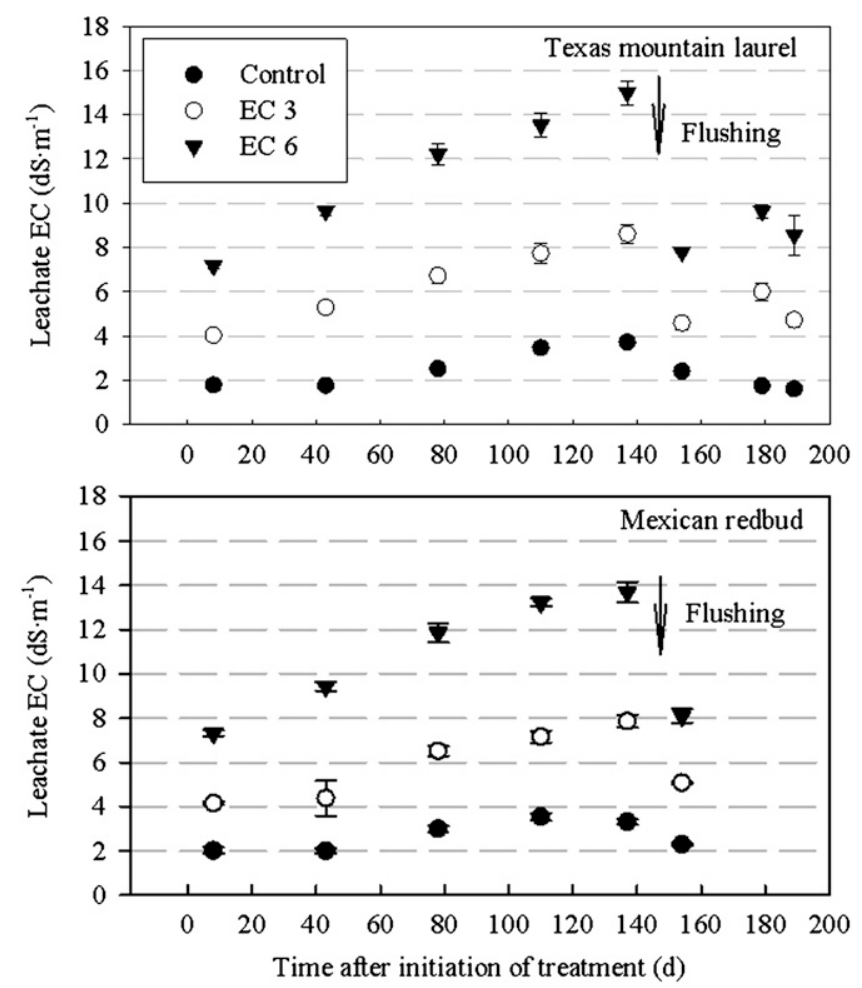

Fig. 1. Leachate electrical conductivity (EC) of Texas mountain laurel (Sophora secundiflora) and Mexican redbud (Cercis canadensis var. mexicana) irrigated with water at EC of 1.6, 3.0, or $6.0 \mathrm{dS} \cdot \mathrm{m}^{-1}$ (control, EC 3, or EC 6). Vertical bars represent SES $(n=8)$. Flushing: all containers were flushed with tap water to leach out salts. 
Plant shoot height of Texas mountain laurel was unaffected in the first 4 months by the salinity of irrigation water (Fig. 2). Six months after the initiation of saline water irrigation, plants irrigated with saline water at $6.0 \mathrm{dS} \cdot \mathrm{m}^{-1}$ were shorter compared with the control and those irrigated at $3.0 \mathrm{dS} \cdot \mathrm{m}^{-1}$. No differences were found among treatments in the number of shoots (data not shown). The final total shoot length of plants irrigated with saline water at $3.0 \mathrm{dS} \cdot \mathrm{m}^{-1}$ and $6.0 \mathrm{dS} \cdot \mathrm{m}^{-1}$ was similar and was $40 \%$ less than control. Shoot DW of plants irrigated with saline water at $3.0 \mathrm{dS} \cdot \mathrm{m}^{-1}$ and $6.0 \mathrm{dS} \cdot \mathrm{m}^{-1}$ was $25 \%$ and $46 \%$ less, respectively, compared with the control. Similar results were observed for the total DW. Root DW of plants irrigated with saline water at 3.0 and $6.0 \mathrm{dS} \cdot \mathrm{m}^{-1}$ was less than that of control.

For Mexican redbud, salinity of irrigation water affected the plant growth as early as 4 months after the initiation of the treatments
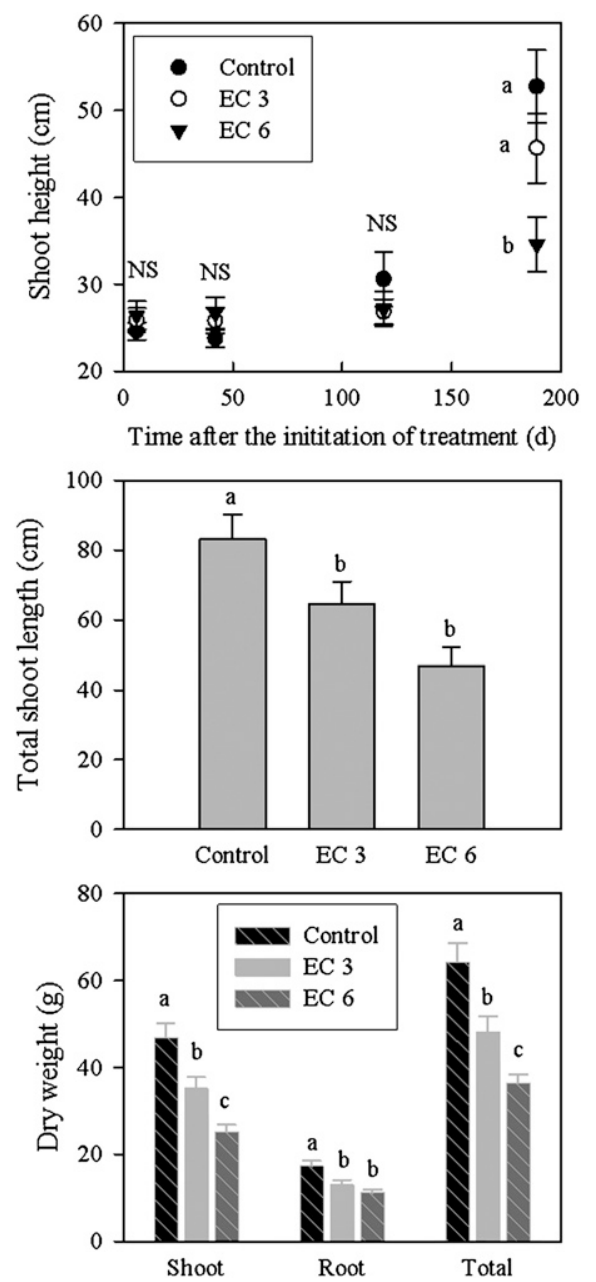

Fig. 2. Plant height, total final shoot length (total length of all shoots), dry weight of shoots, roots, and total of Texas mountain laurel (Sophora secundiflora) irrigated with water at electrical conductivity (EC) of 1.6, 3.0, or 6.0 $\mathrm{dS} \cdot \mathrm{m}^{-1}$ (control, EC 3, or EC 6). Means with same letters were not significantly different according to Student-Newman-Keuls multiple comparison at $P=0.05$. Ns indicates nonsignificance. Vertical bars represent SES $(\mathrm{n}=20)$.
(Fig. 3). Plants irrigated with saline water at $3.0 \mathrm{dS} \cdot \mathrm{m}^{-1}$ and $6.0 \mathrm{dS} \cdot \mathrm{m}^{-1}$ were shorter and shoot growth was slower compared with controls. Total and shoot DW of plants irrigated with saline water at $3.0 \mathrm{dS} \cdot \mathrm{m}^{-1}$ and $6.0 \mathrm{dS} \cdot \mathrm{m}^{-1}$ were over $50 \%$ less and root DW $50 \%$ less compared with controls. Salinity of irrigation water did not affect the number of shoots (data not shown).

Leaf $\mathrm{P}_{\mathrm{n}}, g_{\mathrm{S}}$, and $\mathrm{T}_{\mathrm{r}}$ of Texas mountain laurel plants on a sunny day irrigated with saline water at $3.0 \mathrm{dS} \cdot \mathrm{m}^{-1}$ was $30 \%, 38 \%$, and $24 \%$, respectively, lower than that of control (Fig. 4). Plants irrigated with saline water at $6.0 \mathrm{dS} \cdot \mathrm{m}^{-1}$ had similar $\mathrm{T}_{\mathrm{r}}$ as those irrigated with $3.0 \mathrm{dS} \cdot \mathrm{m}^{-1}$. Although both leaf $\mathrm{P}_{\mathrm{n}}$ and $g_{\mathrm{S}}$ of the plants irrigated at $6.0 \mathrm{dS} \cdot \mathrm{m}^{-1}$ were lower compared with control, there were no differences in $\mathrm{T}_{\mathrm{r}}$. A decreased stomatal aperture is the most dramatic and readily measurable whole plant response to salinity (Munns and Tester, 2008). Lloyd and Howie (1991)
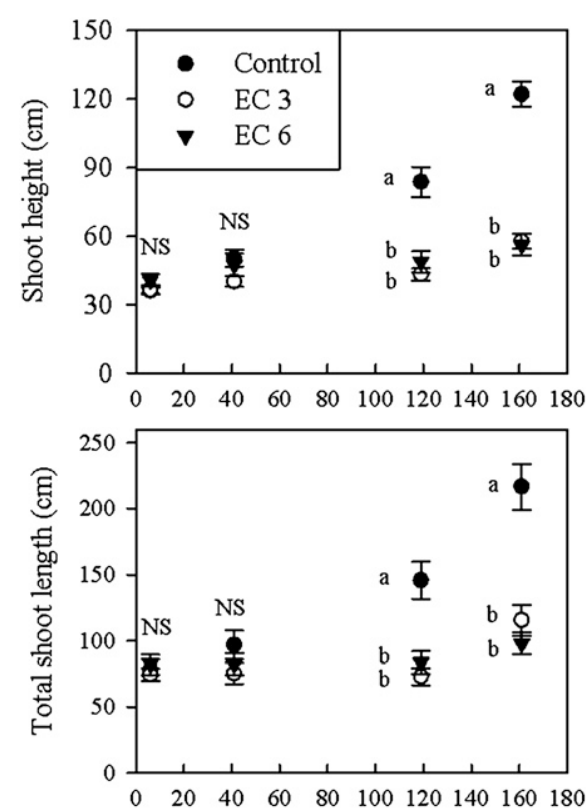

Time after initiation of treatment (d)

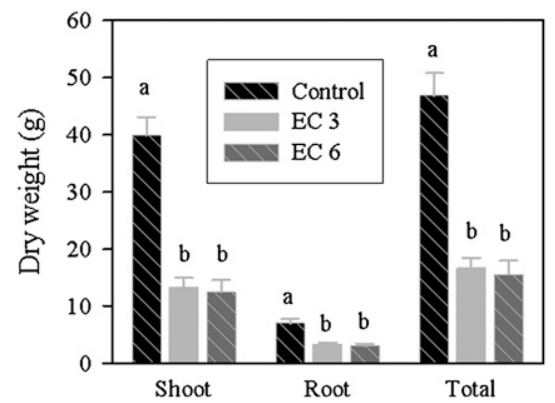

Fig. 3. Plant height, total shoot length (total length of all shoots), dry weight of shoots, roots, and total of Mexican redbud (Cercis canadensis var. mexicana) irrigated with water at electrical conductivity (EC) of $1.6,3.0$, or $6.0 \mathrm{dS} \cdot \mathrm{m}^{-1}$ (control, EC 3, or EC 6). Means with same letters were not significantly different according to Student-Newman-Keuls multiple comparison at $P=0.05$. NS indicates nonsignificance. Vertical bars represent SES $(\mathrm{n}=20)$. found that in the morning, lower values of $g_{\mathrm{S}}$ on orange trees treated with $20 \mathrm{~mol} \cdot \mathrm{m}^{-3} \mathrm{NaCl}$ (although control was $5 \mathrm{~mol} \cdot \mathrm{m}^{-3}$ ) were not caused by more negative water potentials or lower turgor pressures, but by an inability of stomata to function. James et al. (2002) concluded that $g_{\mathrm{S}}$ was the most sensitive indicator of salinity stress followed by $\mathrm{P}_{n}$, compared with fluorescence parameters and also attributed decreased $\mathrm{P}_{\mathrm{n}}$ to both stomatal and nonstomatal limitations.

Plants irrigated with saline water had higher leaf and stem $\mathrm{Na}^{+}$concentrations (Fig. 5). Leaf $\mathrm{Na}^{+}$concentrations of Texas mountain laurel irrigated with saline water at $3 \mathrm{dS} \cdot \mathrm{m}^{-1}$ and $6 \mathrm{dS} \cdot \mathrm{m}^{-1}$ were five and 15 times higher than that in controls, respectively. No difference was found in root $\mathrm{Na}^{+}$concentration between the control and plants irrigated with saline water at $3.0 \mathrm{dS} \cdot \mathrm{m}^{-1}$. The effect of irrigation salinity on tissue $\mathrm{Cl}^{-}$was similar to that on tissue $\mathrm{Na}^{+}$; however, tissue $\mathrm{Cl}^{-}$
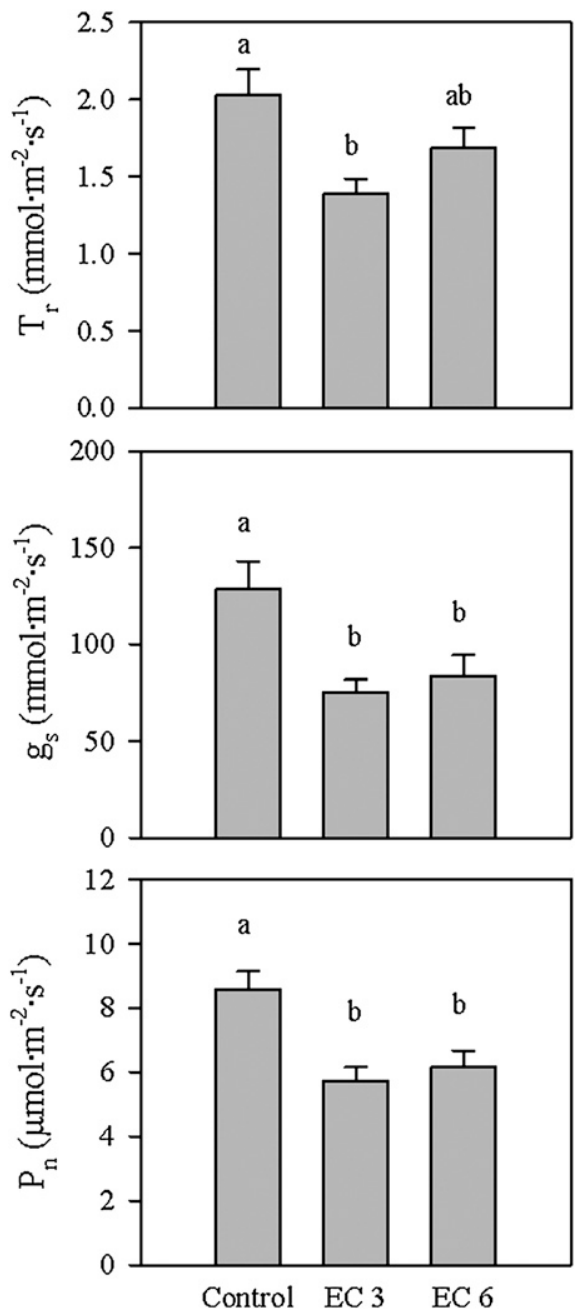

Fig. 4. Leaf gas exchange, transpiration rate $\left(T_{r}\right)$, stomatal conductance $(g \mathrm{~s})$, and net photosynthesis $\left(\mathrm{P}_{\mathrm{n}}\right)$ of Texas mountain laurel (Sophora secundiflora) irrigated with saline water at electrical conductivity (EC) of 1.6, 3.0, or 6.0 $\mathrm{dS} \cdot \mathrm{m}^{-1}$ (control, EC 3, or EC 6). Means with same letters were not significantly different according to Student-Newman-Keuls multiple comparison at $P=0.05$. Vertical bars represent SE $(\mathrm{n}=8)$. 

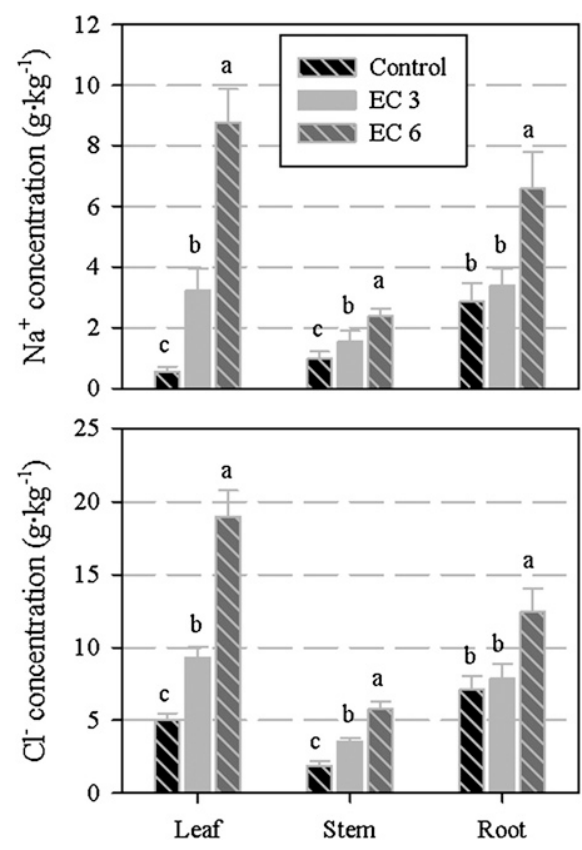

Fig. 5. Tissue sodium $\left(\mathrm{Na}^{+}\right)$and chloride $\left(\mathrm{Cl}^{-}\right)$of Texas mountain laurel (Sophora secundiflora) irrigated with saline water at electrical conductivity (EC) of $1.6,3.0$, or $6.0 \mathrm{dS} \cdot \mathrm{m}^{-1}$ (control, EC 3, or EC 6). Means with the same letters were not significantly different according to Student-Newman-Keuls multiple comparison at $P=0.05$. Vertical bars represent SE $(\mathrm{n}=8)$.

concentrations were higher than those of $\mathrm{Na}^{+}$. Salt-tolerant plants usually exclude $\mathrm{Na}^{+}$uptake or restrict $\mathrm{Na}^{+}$transport from roots to shoots (Munns, 2002). James et al. (2002) found that the nonstomatal limitations of $P_{n}$ were associated with $\mathrm{Na}^{+}$buildup. Wu et al. (2001) tested the salt tolerance of 10 landscape woody ornamental plants and found that salt-tolerant plants accumulated less $\mathrm{Na}^{+}$ and $\mathrm{Cl}^{-}$in leaves than susceptible plants.

Salinity tolerance can be assessed based on the duration for tolerating salinity stress without reduction in growth, yield, or quality and the degree of reduction resulting from salinity stress. According to this criterion, Mexican redbud was less tolerant to salinity stress compared with Texas mountain laurel. In addition to salinity of the irrigation water, salinity tolerance was affected by growing conditions (Fox et al., 2005; Niu et al., 2007). This experiment was conducted in the greenhouse during winter when the light and temperature were relatively low, which could have limited water uptake in the plants. These plants may have shown slower growth earlier if they are irrigated with the same saline solutions under higher temperature and light conditions.

Salt accumulation is a potential problem when poor-quality saline water is used for landscape irrigation. Salt accumulation often depends on soil type and is aggravated by low rainfall. Well-drained and sandy soils accumulate less salts because of more leaching, whereas loam and sandy loam ones accumulate more salts, which lead to salt buildup quickly (Marosz, 2004). Based on the results in the current study, we conclude that Mexican redbud is not suitable to be planted in landscape where poor-quality water may be used. Niu et al. (2007) concluded that salt tolerance of several herbaceous plants obtained from greenhouse studies using soilless potting media was consistent with that from a field study. Although Texas mountain laurel plants were more tolerant to salt stress than Mexican redbud, it would be desirable to further test their tolerance to salt stress in a field condition before planting them in a landscape subject to poor-quality saline water or high soil salinity.

\section{Literature Cited}

Bernstein, N., B.T. Asher, F. Haya, S. Pini, R. Ilona, C. Amram, and I. Marina. 2006. Application of treated wastewater for cultivation of roses (Rosa hybrida) in soil-less culture. Scientia Hort. 108:185-193.

Bole, J.B., J.M. Carefoot, C. Chang, and M. Oosterveld. 1981. Effect of waste water irrigation and leaching percentage on soil and ground water chemistry. J. Environ. Qual. 10:177-183.

Devitt, D.A., R.L. Morris, and L.K. Fenstermaker. 2005. Foliar damage, spectral reflectance, and tissue ion concentrations of trees sprinkle irrigated with waters of similar salinity but different chemical composition. HortScience 40:819-826.

Dobrowolski, J., M. O'Neill, L. Duriancik, and J. Throwe (eds.). 2008. Opportunities and challenges in agricultural water reuse: Final report. USDA-CSREES.

Fox, L.J., J.N. Grose, B.L. Appleton, and S.J. Donohue. 2005. Evaluation of treated effluent as an irrigation source for landscape plants. J. Environ. Hort. 23:174-178.

Gilman, E.F. and D.G. Watson. 1993. Cercis mexicana (Mexican redbud). Florida Cooperative Extension Service, Fact Sheet ST-151, University of Florida.
Gilman, E.F. and D.G. Watson. 1994. Sophora secundiflora (Texas mountain laurel). Florida Cooperative Extension Service, Fact Sheet ST597, University of Florida.

Gori, R., F. Ferrini, F.P. Nicese, and C. Lubello. 2000. Effect of reclaimed wastewater on the growth and nutrient content of three landscape shrubs. J. Environ. Hort. 18:108-114.

James, R.A., A.R. Rivelli, R. Munns, and S. von Caemmerer. 2002. Factors affecting $\mathrm{CO}_{2}$ assimilation, leaf injury and growth in saltstressed durum wheat. Funct. Plant Biol. 29: 1393-1403.

Ku, C.S.M. and D.R. Hershey. 1991. Leachate electrical conductivity and growth of potted poinsettia with leaching fractions of 0 to 0.4 . J. Amer. Soc. Hort. Sci. 116:802-806.

Lloyd, J. and H. Howie. 1991. Salinity, stomatal responses and whole-tree hydraulic conductivity of orchard 'Washington Navel' orange, Citrus sinensis (L.) Osbeck. Austr. J. Plant Physiol. 16:169-179.

Marosz, A. 2004. Effect of soil salinity on nutrient uptake, growth, and decorative value of four ground cover shrubs. J. Plant Nutr. 27:977989.

Miyamoto, S., A. Chacon, M. Hossain, and I. Martinez. 2005. Soil salinity of urban turf areas irrigated with saline water. I. Spatial variability. Landsc. Urban Plan. 71:233-241.

Munns, R. 2002. Comparative physiology of salt and water stress. Plant Cell Environ. 25:239250 .

Munns, R. and M. Tester. 2008. Mechanisms of salinity tolerance. Annu. Rev. Plant Biol. 59: 651-681.

Niu, G. and D.S. Rodriguez. 2006a. Relative salt tolerance of five herbaceous perennials. HortScience 41:1493-1497.

Niu, G. and D.S. Rodriguez. 2006b. Relative salt tolerance of selected herbaceous perennials and groundcovers. Scientia Hort. 110:352-358

Niu, G., D.S. Rodriguez, and L. Aguiniga. 2007. Growth and landscape performance of ten herbaceous species in response to saline water irrigation. J. Environ. Hort. 25:204-210.

Ruter, J.M. and D.L. Ingram. 1991. Germination and morphology of Sophora secundiflora seeds following scarification. HortScience 26:256257.

U.S. Environmental Protection Agency. 1983. Methods of chemical analysis of water and wastes (EPA-600/4-79-020). U.S. Gov. Print. Office, Washington, DC

Wu, L., X. Guo, and A. Harivandi. 2001. Salt tolerance and salt accumulation of landscape plants irrigated by sprinkler and drip irrigation systems. J. Plant Nutr. 24:1473-1490.

Zollinger, N., R. Koenig, T. Cerny-Koenig, and R. Kjelgren. 2007. Relative salinity tolerance of intermountain western United States native herbaceous perennials. HortScience 42:529534. 